\title{
Orthodontic materials with fluoride have an antimicrobial ability for the prevention of white spot lesions
}

\section{Ortodontski materijali s fluoridom imaju antimikrobnu sposobnost za prevenciju karijesnih lezija}

\author{
Sokol Krasniqi ${ }^{1}$, Çeljana Toti ${ }^{2}$, David Stubljar ${ }^{3}$, Tomislav Jukic ${ }^{4}$, Andrej Starc ${ }^{5}$, \\ Tomislav Rukavina ${ }^{6}$, Vanja Vasiljev ${ }^{6}$, Xhevdet Aliu ${ }^{7 *}$
}

\begin{abstract}
Aim: Orthodontic brackets during their wear cause demineralization of enamel, which is the initial step in caries development. The prevention of such spots is crucial to ensure healthy teeth, but patients' compliance is not the most optimal way. The aim of this study was to compare the antimicrobial properties of fluoride-containing orthodontic materials to the materials without additional fluoride. Materials and Methods: Antibacterial effectiveness of orthodontic materials with fluoride - Transbond Plus SEP Bonding agent, Transpond Plus Adhesive agent, Fuji I Band cement, Fuji Ortho LC Adhesive agent, Ortho Solo Bonding agent, and without antimicrobial substances - Transpond XT Bonding agent, Transbond XT Primer were tested with the inhibition on most common causes L. achidophilus (ATCC 4356) and S. mutans (ATCC 10449) and compared to negative control. Antimicrobial effectiveness of each material was measured with the agar diffusion method and expressed with the diameters of inhibition zones around the disk. Results: Materials containing fluoride showed more antimicrobial effectiveness compared to materials without fluoride or negative control $(p<0.001)$, respectively. Materials from the group with no antibacterial substances were not statistically different compared to the negative control $(P>0.05)$. Conclusion: Materials containing fluoride showed more significant antimicrobial effectiveness when compared to the materials without antimicrobial substance and thus might have the potential of antimicrobial properties in vivo.
\end{abstract}

Key words: antimicrobial agents; fluoride; orthodontic adhesives; white spot lesions

\author{
${ }^{1}$ University of Pristina, Faculty of Medicine, \\ Pristina, Kosovo \\ ${ }^{2}$ University of Medicine, Faculty of Dental \\ Medicine, Tirana, Albania \\ ${ }^{3}$ In-Medico, Department of Research and \\ Development, Metlika, Slovenia \\ ${ }^{4}$ Department of Internal medicine, \\ University Josip Juraj Strossmayer Osijek, \\ Faculty of Medicine Osijek, Osijek, Croatia \\ ${ }^{5}$ Faculty of Health Sciences, Chair of Public \\ Health, University of Ljubljana, Ljubljana, \\ Slovenia \\ ${ }^{6}$ Department of Public Health, University of \\ Rijeka, Faculty of Medicine, Rijeka, Croatia \\ ${ }^{7}$ Faculty of Dentistry, University for Business \\ and Technology, Pristina, Kosovo
}

\begin{abstract}
Sažetak. Cilj: Ortodontski breketi tijekom nošenja uzrokuju demineralizaciju cakline, što je početni korak u razvoju karijesa. Prevencija takvih mrlja presudna je za osiguravanje zdravih zuba, ali suradljivost pacijenata nije uvijek optimalna. Cilj ovog istraživanja bio je usporediti antimikrobna svojstva ortodontskih materijala koji sadrže fluorid s materijalima bez dodatnog fluorida. Materijal i metode: Antibakterijsku učinkovitost ortodontskih materijala s fluoridom - Transbond Plus SEP Bonding agent, Transpond Plus ljepilo, Fuji I Band cement, Fuji Ortho LC ljepilo, Orto Solo Bonding agent, i učinkovitost ortodontskih materijala bez antimikrobnih tvari - Transpond XT Bonding agent, Transbond XT Primer, testirali smo s inhibicijom na najčešće uzročne bakterije L. achidophilus (ATCC 4356) i S. mutans (ATCC 10449) i usporedili učinkovitost $s$ negativnom kontrolom. Antimikrobna učinkovitost svakog materijala izmjerena je metodom difuzije agara i izražena promjerom zona inhibicije oko diska. Rezultati: Materijali koji sadrže fluorid pokazali su veću antimikrobnu učinkovitost $u$ usporedbi $s$ materijalima bez fluorida ili u usporedbi s negativnom kontrolom $(p<0,001)$. Materijali koji ne sadrže antibakterijske tvari nisu se statistički razlikovali u usporedbi $s$ negativnom kontrolom $(p>0,05)$. Zaključak: Materijali koji sadrže fluorid pokazali su značajniju antimikrobnu učinkovitost u usporedbi s materijalima bez antimikrobne tvari i stoga mogu imati potencijal antimikrobnih svojstava u uvjetima in vivo.
\end{abstract}

Ključne riječi: antimikrobna sredstva; bijele mrlje; fluorid; ortodontski adhezivi

\author{
*Corresponding author: \\ Prof. Ass. Dr. Xhevdet Aliu \\ University for Business and Technology, \\ Faculty of Dentistry Pristina \\ Lagjja Kalabria, 10000 Pristina, Kosovo \\ E-mail:xhevdetaliu99@gmail.com
}

http://hrcak.srce.hr/medicina 


\section{INTRODUCTION}

Orthodontic brackets frequently impair the cleanliness of teeth during their wear ${ }^{1-3}$. It is physically difficult to clean and brush the teeth around the brackets, therefore cariogenic bacteria, such as Lactobacillus acidophilus (L. acidophilus) or Streptococcus mutans (S. mutans), can form biofilm which leads to tooth decay or demineralization around orthodontic brackets ${ }^{4-6}$.

Orthodontic brackets during their wear cause demineralization of enamel, which is the initial step in caries development. The prevention of such spots is crucial to ensure healthy teeth. Fluoride-containing materials showed greater antimicrobial effectiveness but require frequent application of more fluoride to enhance their antimicrobial ability.

Demineralization or development of white spot lesions (WSLs) might disappear through natural remineralization without additional substances once the orthodontic brackets are removed and oral hygiene is restored ${ }^{7}$. However, the removal of the appliances is not always enough, as demineralization spots do not disappear and can last for years ${ }^{8,9}$.

Prevention of WSLs encompasses various strategies. Oral hygiene and dietary control are one thing ${ }^{10}$. but application of fluoride agents as a remineralizing agent, can help remineralize the lesions $^{11}$. Additionally, to the fluoride itself, antimicrobial fluoride-obtaining adhesives have arrived at the market for orthodontic bonding, and these were proven as useful in remineralization $^{12,13}$. Fluoride adsorbs minerals of the enamel and enhances protective mechanisms against acid dissolution, counteracts with bacterial enzymes, which leads to bacterial plaque inactivity, and speeds up the remineralization process by attracting calcium ions in carious lesions ${ }^{14-18}$. As fluoride comes in different forms, the option which rely on patient's compliance and cooperation however is often not reliable ${ }^{19-21}$. Therefore, the solution of incorporation of antimicrobial agents into the orthodontic adhesives (e.g. fluoride-releasing orthodontic adhesives) have shown to be effective in reversing WSLs after debonding ${ }^{15}$.
The aim of our study was to evaluate the antimicrobial effectiveness of fluoride in fluoride-containing orthodontic materials and compare their antimicrobial ability to the materials without additional fluoride.

\section{MATERIALS AND METHODS}

Antimicrobial effect of orthodontic materials containing fluoride were analyzed in vitro. Materials were classified into two different groups; cases with orthodontic materials that contained fluoride and controls with materials that contained to antimicrobial substance. Negative controls were performed with each batch to ensure there was no contamination. The following materials were tested for 10-times; Group 1 containing fluoride - Transbond Plus SEP Bonding agent, Transpond Plus Adhesive agent, Fuji I Band cement, Fuji Ortho LC Adhesive agent, Ortho Solo Bonding agent); Group 2 with no antimicrobial substances - Transpond XT Bonding agent, Transbond XT Primer.

\section{Bacterial samples}

Performance of additional fluoride was tested on two most commonly causes of WSLs L. achidophilus (ATCC 4356) and S. mutans (ATCC 10449) as a bacterial sample. The frozen microbial strains were dissolved and inoculated onto the blood agar plate. The plate was incubated for 48 hours in anaerobic atmosphere at $37{ }^{\circ} \mathrm{C}$ and examined after two days. The bacterial growth was evaluated and confirmed with morphological characteristics (colony shape, colour, thickness, haemolysis on agar plate) and gram staining.

\section{Orthodontic samples}

The standardized quantity of each orthodontic material was created with the plastic mold disk using $10 \mathrm{mg}$ of a respective material. When molded, disks were then placed on freshly inoculated $\mathrm{BHI}$ agar plates. Each plate also contained a negative control with a blank paper disk.

\section{Bacterial culture}

Suspensions of L. acidophilus and S. mutans culture were levelled to $0.5 \mathrm{McF}$ arlands $\left(1.5 \times 10^{9} \mathrm{ce}-\right.$ $\| \mathrm{s} / \mathrm{mL}$ ) and prepared in the thioglycolate broth. 
$200 \mu \mathrm{L}$ of suspension was mixed with $3.5 \mathrm{~mL}$ of soft agar and poured over the BHI agar plate.

\section{Antimicrobial testing}

In-house disk diffusion test was performed. Disk diffusion method of antimicrobial testing was used. Orthodontic disks were placed onto the hardened $\mathrm{BHI}$ agar. The plates containing S. mutans strain were cultivated at $37{ }^{\circ} \mathrm{C}$ under anaerobic conditions for 48 hours. Meanwhile the plates with L. acidophilus were cultivated at $37^{\circ} \mathrm{C}$ under microaerophilic conditions also for 48 hours. Antimicrobial ability of orthodontic materials was evaluated with the measurement of inhibition zones around each disk. Diameter of the zones were measured in millimetres $(\mathrm{mm})$.

\section{Statistical analysis}

Data were analyzed using SPSS 21 (IBM, New York, USA). Two-Way ANOVA with pairwise comparisons was used to assess differences between the effectiveness on different bacterial strains and for the comparisons of orthodontic materials with their mean diameters of inhibition zones. In case of abnormal data distribution Kruskal-Wallis test was used. Statistical significance was set at $P<0.05$ for all comparisons.

\section{RESULTS}

Overall, 160 specimens were tested. The effectiveness with inhibition zones is presented in Table
1. There were no differences in terms of significant effectiveness between the two bacterial strains. L. acidophilus on average showed slightly larger zones of inhibition with agents containing fluoride $(9.1 \pm 2.0 \mathrm{~mm})$ compared to $S$. mutans $(9.0 \pm 3.2 \mathrm{~mm})$, but none of the tested agents showed any significance. Similarly, was observed with the agents without fluoride $(1.2 \pm 1.2 \mathrm{~mm}$ and $0.8 \pm 0.9 \mathrm{~mm}$, respectively). Moreover, the ANOVA showed no statistically significant difference (F-value=20.121; $P=0.100$ ). However, the ANOVA test showed statistically significant differences when comparing orthodontic materials among each other (F-value $=55.081 ; P<0.001)$. Pairwise comparisons with Kruskal-Wallis test showed that all fluoride-containing materials were statistically different to the negative controls $(P<0.001)$, respectively (Table 2$)$. However, materials from Group 2 with no antibacterial substance were not statistically significant when compared to the negative controls ( $P>0.05)$.

Among all orthodontic materials Transbond Plus agents showed the largest zones of inhibition of above $10 \mathrm{~mm}$ in diameter, which was different to other materials. Furthermore, fluoride-containing orthodontic materials showed statistically better antimicrobial effectiveness when compared to the materials from Group 2, without additional antimicrobial substance. On average diameter was $9.1 \pm 2.6 \mathrm{~mm}$ versus $0.9 \pm 1.0 \mathrm{~mm}$. These showed significantly less antimicrobial ef-

Table 1. Antimicrobial effectiveness on L. acidophilus and S. mutans with the zones of inhibition for a respective group of orthodontic materials

\begin{tabular}{|c|c|c|c|c|c|}
\hline \multirow{2}{*}{$\begin{array}{l}\text { Antimicrobial } \\
\text { agent }\end{array}$} & \multirow[b]{2}{*}{ Orthodontic material } & \multirow{2}{*}{$\begin{array}{c}\text { TOTAL [mm] } \\
\qquad \begin{array}{l}\mathrm{N}=160\end{array}\end{array}$} & \multicolumn{2}{|c|}{ Zone of inhibition } & \multirow[b]{2}{*}{$p$-value } \\
\hline & & & $\begin{array}{l}\text { L. acidophilus [mm] } \\
\qquad(\mathrm{n}=80)\end{array}$ & $\begin{array}{l}\text { S. mutans }[\mathrm{mm}] \\
(\mathrm{n}=80)\end{array}$ & \\
\hline \multirow{6}{*}{ Fluoride } & Transbond Plus SEP bonding agent $(n=20)$ & $10.4 \pm 3.8$ & $9.3 \pm 1.9$ & $11.2 \pm 5.1$ & 0.108 \\
\hline & Transbond Plus adhesive agent $(n=20)$ & $10.3 \pm 2.8$ & $10.6 \pm 2.6$ & $9.8 \pm 3.1$ & 0.587 \\
\hline & Fuji I band cement ( $n=20)$ & $8.2 \pm 2.5$ & $8.5 \pm 2.6$ & $8.0 \pm 2.5$ & 0.489 \\
\hline & Fuji Ortho LC adhesive agent $(n=20)$ & $7.8 \pm 1.4$ & $8.2 \pm 1.5$ & $7.4 \pm 1.3$ & 0.357 \\
\hline & Ortho solo bonding agent $(n=20)$ & $8.5 \pm 1.6$ & $8.6 \pm 1.2$ & $8.4 \pm 2.0$ & 0.734 \\
\hline & Total & $9.1 \pm 2.6$ & $9.1 \pm 2.0$ & $9.0 \pm 3.2$ & 0.086 \\
\hline \multirow{4}{*}{ None } & Transbond XT bonding agent $(n=20)$ & $1.1 \pm 1.0$ & $1.3 \pm 1.1$ & $0.9 \pm 1.0$ & $0.765^{*}$ \\
\hline & Transbond XT primer $(n=20)$ & $0.9 \pm 1.0$ & $1.1 \pm 1.1$ & $0.8 \pm 0.8$ & $0.924 *$ \\
\hline & Total & $0.9 \pm 1.0$ & $1.2 \pm 1.2$ & $0.8 \pm 0.9$ & $0.603 *$ \\
\hline & Negative control $(n=20)$ & $0.0 \pm 0.0$ & $0.0 \pm 0.0$ & $0.0 \pm 0.0$ & 1.000 \\
\hline
\end{tabular}

\footnotetext{
* Kruskal-Wallis test was used for comparisons between the effectiveness on different bacterial strains
} 
Table 2. Pairwise comparisons between the orthodontic materials for combined effectiveness data on L. acidophilus and S. mutans

\begin{tabular}{|l|c|c|c|c|c|c|c|c|}
\hline & $\begin{array}{c}\text { Transbond } \\
\text { Plus SEP } \\
\text { bonding } \\
\text { agent }\end{array}$ & $\begin{array}{c}\text { Transbond } \\
\text { Plus } \\
\text { adhesive } \\
\text { agent }\end{array}$ & $\begin{array}{c}\text { Fuji I band } \\
\text { cement }\end{array}$ & $\begin{array}{c}\text { Fuji Ortho } \\
\text { LC adhesive } \\
\text { agent }\end{array}$ & $\begin{array}{c}\text { Ortho solo } \\
\text { bonding } \\
\text { agent }\end{array}$ & $\begin{array}{c}\text { Transbond } \\
\text { XT bonding } \\
\text { agent }\end{array}$ & $\begin{array}{c}\text { Transbond } \\
\text { XT primer }\end{array}$ & $\begin{array}{c}\text { Negative } \\
\text { control }\end{array}$ \\
\hline $\begin{array}{l}\text { Transbond Plus SEP } \\
\text { bonding agent }\end{array}$ & 1 & 0.185 & 0.007 & $<0.001$ & 0.014 & $<0.001$ & $<0.001$ & $<0.001$ \\
\hline $\begin{array}{l}\text { Transbond Plus } \\
\text { adhesive agent }\end{array}$ & 0.185 & 1 & 0.091 & 0.039 & 0.259 & $<0.001$ & $<0.001$ & $<0.001$ \\
\hline Fuji I band cement & 0.007 & 0.091 & 1 & 0.560 & 0.684 & $<0.001$ & $<0.001$ & $<0.001$ \\
\hline $\begin{array}{l}\text { Fuji Ortho LC } \\
\text { adhesive agent }\end{array}$ & $<0.001$ & 0.039 & 0.631 & 1 & 0.329 & $<0.001$ & $<0.001$ & $<0.001$ \\
\hline $\begin{array}{l}\text { Ortho solo bonding } \\
\text { agent }\end{array}$ & 0.014 & 0.259 & 0.734 & 0.329 & 1 & $<0.001$ & $<0.001$ & $<0.001$ \\
\hline $\begin{array}{l}\text { Transbond XT } \\
\text { bonding agent }\end{array}$ & $<0.001$ & $<0.001$ & $<0.001$ & $<0.001$ & $<0.001$ & 1 & 0.934 & 0.411 \\
\hline $\begin{array}{l}\text { Transbond XT } \\
\text { primer }\end{array}$ & $<0.001$ & $<0.001$ & $<0.001$ & $<0.001$ & $<0.001$ & 0.934 & 1 \\
\hline Negative control & $<0.001$ & $<0.001$ & $<0.001$ & $<0.001$ & $<0.001$ & 0.411 & 0.472 & 0.472 \\
\hline
\end{tabular}

* Pairwise comparisons between the orthodontic materials were tested with series of ANOVA tests or Kruskal-Wallis test

fectiveness and where not statistically different compared to negative controls (Table 2).

\section{DISCUSSION}

Enamel demineralization of WSLs are frequent problem after removal of orthodontic brackets. Different treatment and prevention measures have been proposed, which are fully dependable on patients' compliance and physician choice ${ }^{22}$. Preventing WSLs is important in order to obtain more aesthetic results after debonding of brackets. There is the increase in the number of substances that can be used to prevent these lesions, and application of fluoride in different forms has showed great effectiveness in the prevention of not only bacterial growth and caries, but also in the prevention of such lesions ${ }^{23,24}$. The aim of the current study was to determine whether fluoride-containing orthodontic materials have an advantage in the prevention of WSLS than compared to the materials without antimicrobial substances. Fluoride-containing adhesives to prevent enamel demineralization were used in previous studies and showed encouraging results $^{25,26}$.

Table 1 summarizes the zones of inhibition for orthodontic material according against L. acidophilus and S. mutans. The fluoride-containing orthodontic materials inhibited the growth of $L$. acidophilus and S. mutans, measured with the inhibition zones with disk diffusion method and showed antimicrobial effect against both. Past studies proved that fluoride has the antimicrobial ability against oral microorganisms $s^{7,16,17,27,28}$. In our study also the materials with no incorporated antimicrobial substances from Group 2 showed some antimicrobial efficacy, implying that orthodontic adhesives on their own might have some antimicrobial activity, but these were not statistically significant when compared to the negative controls.

Fluoride-containing orthodontic materials showed significantly larger zone of inhibition than the materials without fluoride. Materials with no antimicrobial substance showed no or extremely poor antimicrobial effectiveness. These results coincide with the findings by Kelly ${ }^{29}$, who reported that orthodontic materials with no additional incorporation of antimicrobial substances do not inhibit the growth of bacteria and do not form an inhibition zone. A poor inhibition was observed in our analysis. As the material itself cannot diffuse into the agar, therefore cannot have an antimicrobial ability, but small inhibition zone might occur due to material physical restrictions for bacterial growth.

The results of our study showed that Transbond Plus SEP bonding agent containing fluoride pro- 
ved to have the greatest antimicrobial effectiveness compared to all other tested materials. The comparisons were statistically significantly different to all tested materials, except when compared to Transbond Plus adhesive agent $(P=0.185)$. There results suggest that an amount of incorporated fluoride is the main reason for the difference of the results in the matter or inhibition zones for a given type of the material. In our study it was proven that all fluoride-containing materials had shown antimicrobial effectiveness, as they were statistically significant when compared to negative controls or even to materials without incorporated fluoride. Other studies are in line with the results of our current study and reported antibacterial effectiveness for Fuji I, Fuji Ortho LC, Ortho solo, and Transbond Plus, and no effectiveness for Transbond XT bonding agent and Transbond XT primer with the same dish diffusion method and bacterial growth inhibition zones $^{29}$. Therefore, fluoride confirmed that it has antibacterial effectiveness.

The incorporation of fluoride into the orthodontic material itself showed several advantages over the materials without fluoride. Thus, providing higher effectiveness also in vivo models. The effectiveness of fluoride against $L$. acidophilus and $S$. mutans, as the most frequent causes of development of WSLs, has therefore the potential to prevent growth of this cariogenic bacteria and prevent the development of caries and WSLs. As mentioned, the positive effectiveness of fluoride proved in the current study coincides with the findings of previous reports, still suggesting fluoride is the antimicrobial agent of choice when establishing health oral cavity ${ }^{30}$. Although fluoride provides a significant benefit, the only disadvantage of fluoride in various forms is that it requires often applications in order to ensure the continuous effectiveness $22,25,31$. Over time, the effectiveness of orthodontic materials containing fluoride require application of more fluoride to enhance their antimicrobial ability.

Orthodontic materials with incorporated antimicrobial substances, such as fluoride, can act as modern and powerful assets for orthodontists to maintain the growth of cariogenic bacteria, and thus prevent the WSLs as an initial steps of caries development. The results obtained from this study clearly show that fluoride might have the potential to increase the preventive measures of WSLs development in vivo. However, this study had limitations. The study was small, investigating only 7 respective orthodontic materials and include only the materials with and without fluoride. Nowadays, orthodontists use materials that have incorporation of various antimicrobial substances, but these were not used in this study. It would be interesting to analyze the antimicrobial

In vitro study does not simulate the full oral cavity conditions of in vivo conditions. As there is not a lot of studies on the maintaining effect of incorporated fluoride it is unclear antimicrobial effectiveness are maintained during the wearing of orthodontic brackets. Therefore, fluoride-containing materials need to be studied more often also with other adhesive materials for the prevention of WSLs during orthodontic therapy.

effectiveness of all more agents. Our study also did not simulate the full oral cavity conditions, as for instance artificial saliva was not used. Therefore, limitations of in vitro tests include the lack of application into in vivo conditions.

\section{CONCLUSIONS}

Disk diffusion method showed that orthodontic materials containing fluoride have antimicrobial ability. Furthermore, as there is not a lot of studies on the maintaining effect of incorporated fluoride it is unclear antimicrobial effectiveness are maintained during the wearing of orthodontic brackets. Fluoride-containing materials showed greater antimicrobial effectiveness but require frequent application of more fluoride to enhance their antimicrobial ability. However, fluoride-containing materials have shown the potential to prevent the development of WSLs during orthodontic therapy.

\section{ACKNOWLEDGEMENTS}

All authors have made substantive contribution to this study and/or manuscript, and all have reviewed the final paper prior to its submission. No funding was received. 
Conflicts of interest: Authors declare no conflict of interest.

\section{REFERENCES}

1. Jordan C, Leblanc DJ. Influences of orthodontic appliances on oral populations of mutans streptococci. Oral Microbiol Immunol 2002;17:65-71.

2. Anhoury P, Nathanson D, Hughes CV, Socransky S, Feres M, Chou LL. Microbial profile on metallic and ceramic bracket materials. Angle Orthod 2002;72:338-43.

3. Lessa FC, Enoki C, Ito IY, Faria G, Matsumoto MA, Nelson-Filho $P$. In vivo evaluation of the bacterial contamination and disinfection of acrylic baseplates of removable orthodontic appliances. Am J Orthod Dentofacial Orthop 2007;131:11-7.

4. Whittaker CJ, Klier CM, Kolenbrander PE. Mechanisms of adhesion by oral bacteria. Annu Rev Microbiol 1996;50: 513-52.

5. De Stoppelaar JD, van HJ, Backer DO. The relationship between extracellular polysaccharide-producing streptococci and smooth surface caries in 13-year-old children. Caries Res 1969;3:190-9.

6. Loesche WJ. Role of Streptococcus mutans in human dental decay. Microbiol Rev 1986;50:353-80.

7. Ogaard B, Larsson E, Henriksson T, Birkhed D, Bishara SE. Effects of combined application of antimicrobial and fluoride varnishes in orthodontic patients. Am J Orthod Dentofacial Orthop 2001;120:28-35.

8. Shungin D, Olsson Al, Persson M. Orthodontic treatmentrelated white spot lesions: a 14-year prospective quantitative follow-up, including bonding material assessment. Am J Orthod Dentofacial Orthop 2010;138:136-7.

9. Ogaard B. Prevalence of white spot lesions in 19-yearolds: A study on untreated and orthodontically treated persons 5 years after treatment. Am J Orthod Dentofacial Orthop 1989;96:423-7.

10. Millett DT, Nunn JH, Welbury RR, Gordon PH. Decalcification in relation to brackets bonded with glass ionomer cement or a resin adhesive. Angle Orthod 1999;69:65-70.

11. Reynolds E, Cai F, Cochrane N, Shen P, Walker GD, Morgan $\mathrm{MV}$ et al. Fluoride and casein phosphopeptide-amorphous calcium phosphate. J Dent Res 2008;87:344-8.

12. $\mathrm{Oz} A Z, \mathrm{Oz} A \mathrm{~A}$, Yazıcıoglu S. In vivo effect of antibacterial and fluoride-releasing adhesives on enamel demineralization around brackets: A micro-CT study. Angle Orthod 2017;87:841-6.

13. Cate Jt. Review on fluoride, with special emphasis on calcium fluoride mechanisms in caries prevention. Eur J Oral Sci 1997;105:461-5.

14. Geiger AM, Gorelick L, Gwinnett AJ, Benson BJ. Reducing white spot lesions in orthodontic populations with fluoride rinsing. Am J Orthod Dentofacial Orthop 1992;101:403-7.

15. Du M, Cheng N, Tai B, Jiang H, Li J, Bian Z. Randomized controlled trial on fluoride varnish application for treatment of white spot lesion after fixed orthodontic treatment. Clin Oral Investig 2012;16:463-8.

16. Schmit JL, Staley RN, Wefel JS, Kanellis M, Jacobsen JR, Keenan PJ. Effect of fluoride varnish on demineralization adjacent to brackets bonded with RMGI cement. Am J Orthod Dentofacial Orthop 2002;122:125-34.

17. Todd MA, Staley RN, Kanellis MJ, Donly KJ, Wefel JS. Effect of fluoride varnish on demineralization adjacent to orthodontic brackets. Am J Orthod Dentofacial Orthop 1999;116:159-67.

18. Sudjalim TR, Woods MG, Manton DJ, Reynolds EC. Prevention of demineralization around orthodontic brackets: in vitro. Am J Orthod Dentofacial Orthop 2007;131:1-9.

19. Badawi H, Evans RD, Wilson M, Ready D, Noar JH, Pratten J. The effect of orthodontic bonding materials on dental plaque accumulation and composition in vitro. Biomaterials 2003;24:3345-50.

20. Li S, Hobson RS, Bai Y, Yan Z, Carrick TE, Mccabe JF. A method for producing controlled fluoride release from an orthodontic bracket. Eur J Orthod 2007;29:550-4.

21. Ahmed RA, Fadl-Allah SA, El-Bagoury N, El-Rab SMFG. Improvement of corrosion resistance and antibacterial effect of NiTi orthopedic materials by chitosan and gold nanoparticles. Appl Surf Sci 2014;292:390-9.

22. Derks A, Katsaros C, Frencken J, Van't Hof M, KuijpersJagtman A. Caries-inhibiting effect of preventive measures during orthodontic treatment with fixed appliances. Caries Res 2004;38:413-20.

23. Benson PE, Parkin N, Millett DT, Dyer FE, Vine S, Shah A. Fluorides for the prevention of white spots on teeth during fixed brace treatment. Cochrane Database Syst Rev 2004;3:1-47.

24. Cosma LL, Şuhani RD, Mesaroş A, Badea ME. Current treatment modalities of orthodontically induced white spot lesions and their outcome - a literature review. Med Pharm Rep 2019;92:25-30.

25. Paschos $E$, Kleinschrodt $T$, Clementino-Luedemann $T$, Huth KC, Hickel R, Kunzelmann KH et al. Effect of different bonding agents on prevention of enamel demineralization around orthodontic brackets. Am J Orthod Dentofacial Orthop 2009;135:603-12.

26. Uysal T, Amasyali M, Ozcan S, Koyuturk AE, Sagdic D. Effect of antibacterial monomer-containing adhesive on enamel demineralization around orthodontic brackets: an in-vivo study. Am J Orthod Dentofacial Orthop 2011;139:650-6.

27. Benson PE, Shah AA, Millett DT, Dyer F, Parkin N, Vine RS. Fluorides, orthodontics and demineralization: a systematic review. J Orthod 2005;32:102-14.

28. Chadwick SM, Gordon PH. An investigation to estimate the fluoride uptake adjacent to a fluoride-releasing bonding agent. Br J Orthod 1995;22:113-22.

29. Kelly MT. An in vitro study of antimicrobial properties of an orthodontic sealant/adhesive containing selenium. Chapel Hill, USA: University of North Carolina, 2020. Master thesis.

30. Vivaldi-Rodrigues G, Demito CF, Bowman SJ, Ramos AL. The effectiveness of a fluoride varnish in preventing the development of white spot lesions. World J Orthod 2006; 7:138-44.

31. Tran P, Hamood A, Mosley T, Gray T, Jarvis C, Webster D et al. Organo-Selenium-containing Dental Sealant Inhibits Bacterial Biofilm. J Dent Res 2013;92:461-6. 